\title{
4RESPON PERTUMBUHAN BIBIT KAKAO (Theobroma cacao L.) DENGAN PEMBERIAN BERBAGAI KONSENTRASI PGPR (Plant Growth Promoting Rhizobacteria) AKAR KAKAO
}

\author{
Triono Bambang Irawan ${ }^{1}$, Liliek Dwi Soelaksini ${ }^{2}$, Anni Nuraisyah ${ }^{3}$ \\ ${ }^{1,3}$ Program Studi Budidaya Tanaman perkebunan, Jurusan Produksi Pertanian, \\ Politeknik Negeri Jember \\ Jl. Mastrip 164 Jember \\ ${ }^{2}$ Program Studi Teknologi Produksi Tanaman Pangan, Jurusan Produksi Pertanian, \\ Politeknik Negeri Jember \\ Jl. Mastrip 164 Jember \\ email : triono_bambang@polije.ac.id
}

Submitted: 30 Desember 2021 Accepted: 12 Januari 2022 Approved: 13 Januari 2022

\begin{abstract}
ABSTRAK
Tujuan penelitian ini adalah : (i) mengetahui respon pertumbuhan bibit kakao dengan pemberian PGPR akar kakao; (ii) mengetahui konsentrasi PGPR akar kakao yang tepat untuk pertumbuhan bibit kakao. Penelitian dilaksanakan pada bulan Juni - Desember 2021, bertempat di lahan pembibitan Politeknik Negeri Jember dengan ketinggian tempat $89 \mathrm{~m}$ dpl. Penelitian menggunakan RAK non faktorial, yaitu : PO = Konsentrasi PGPR $0 \mathrm{ml} /$ liter / 5 polibag; P1 = Konsentrasi PGPR $50 \mathrm{ml} /$ liter $/ 5$ polibag; P2= Konsentrasi PGPR $100 \mathrm{ml} /$ liter / 5 polibag; P3 = Konsentrasi PGPR $150 \mathrm{ml} /$ liter / 5 polibag dan 6 ulangan. Hasil penelitian menunjukkan : (i) Respon pertumbuhan bibit kakao dengan pemberian PGPR (Plant Growth Promoting Rhizobacteria) Akar Kakao berpengaruh nyata terhadap tinggi tanaman, jumlah daun, diameter batang, berat basah dan berat kering akar, jumlah akar dan volume akar; (ii) Pemberian konsentrasi PGPR akar kakao yang optimal terhadap berat kering akar : $109 \mathrm{ml} /$ I dan berat basah akar : $99 \mathrm{ml} /$ l.
\end{abstract}

Kata Kunci:Plant Growth Promoting Rhizobacteria, Bibit Kakao

\section{ABSTRACT}

The aims of this study were: (i) to determine the response of cocoa seedling growth to cocoa root PGPR; (ii) determine the appropriate PGPR concentration of cocoa roots for the growth of cocoa seedlings. The research was carried out in June - December 2021, located in the Jember State Polytechnic nursery with an altitude of $89 \mathrm{~m}$ above sea level. The study used non-factorial RAK, namely: $P O=P G P R$ concentration $0 \mathrm{ml} /$ liter/5 polybags; $P 1=P G P R$ concentration $50 \mathrm{ml} /$ liter $/ 5$ polybags; $P 2=P G P R$ concentration $100 \mathrm{ml} /$ liter $/ 5$ polybags; $P 3=P G P R$ concentration $150 \mathrm{ml} /$ liter / 5 polybags and 6 replications. The results showed: (i) Cocoa seedling growth response by giving PGPR (Plant Growth Promoting Rhizobacteria) Cocoa Roots had a significant effect on plant height, number of leaves, stem diameter, wet weight and dry weight of roots, number of roots and root volume; (ii) Provision of optimal PGPR concentration of cocoa roots on root dry weight : $109 \mathrm{ml} / \mathrm{l}$ and root wet weight : $99 \mathrm{ml} / \mathrm{l}$.

Keywords: Plant Growth Promoting Rhizobacteria, Cocoa Seeds

\section{PENDAHULUAN}

Plant Growth Promoting Rhizobacteria (PGPR) adalah bakteri menguntungkan yang agresif mengkolonisasi rizosfir (lapisan tanah tipis antara 1-2 $\mathrm{mm}$ di sekitar zona perakaran).Aktivitas PGPR memberi keuntungan bagi pertumbuhan tanaman, baik secara langsung maupun secara tidak langsung.Pengaruh langsung PGPR didasarkan atas kemampuannya menyediakan dan memobilisasi atau memfasilitasi penyerapan berbagai unsur hara dalam tanah serta mensintesis dan mengubah konsentrasi berbagai fitohormon pemacu tumbuh. Sedangkan pengaruh tidak langsung berkaitkan dengan kemampuan PGPR menekan aktivitas patogen dengan cara menghasilkan berbagai senyawa atau metabolit seperti antibiotik dan siderophore (Kloepper et al., 1991; Kloepper, 1993; Glick, 1995).

Sebagian besar bakteri PGPR berasal dari kelompok gram-negatif dengan jumlah strain paling banyak dari genus Pseudomonas dan 
beberapa dari genus Serratia. Selain kedua genus tersebut, dilaporkan antara lain dari genus Azotobacter, Azospirillum, Acetobacter, Burkholderia, dan Bacillus. Meskipun sebagian besar Bacillus (gram-positif) tidak tergolong pengkoloni akar, beberapa strain tertentu dari genus ini ada yang mampu melakukannya, sehingga bisa digolongkan sebagai PGPR.

Fungsi PGPR dalam meningkatkan pertumbuhan tanaman dibagi dalam tiga kategori, yaitu: (i) sebagai pemacu / perangsang pertumbuhan (biostimulants) dengan mensintesis dan mengatur konsentrasi berbagai zat pengatur tumbuh (fitohormon) seperti asam indol asetat (AIA), giberellin, sitokinin, dan etilen dalam lingkungan akar; (ii) sebagai penyedia hara (biofertilizers) dengan menambat N2 dari udara secara asimbiosis dan melarutkan hara $\mathrm{P}$ yang terikat di dalam tanah; dan (iii) sebagai pengendali patogen berasal dari tanah (bioprotectants) dengan cara menghasilkan berbagai senyawa atau metabolit anti patogen seperti siderophore, $\beta$ 1,3-glukanase, kitinase, antibiotik, dan sianida (Tenuta, 2006; Cattelan et al.,1999; Kloepper, 1993).

Lingkungan rizosfir yang dinamis dan kaya akan sumber energi dari senyawa organik yang dikeluarkan oleh akar tanaman (eksudat akar) merupakan habitat bagi berbagai jenis mikroba untuk berkembang dan sekaligus sebagai tempat pertemuan dan persaingan mikroba (Sorensen,1997). Tiap tanaman mengeluarkan eksudat akar dengan komposisi yang berbeda-beda sehingga berperan juga sebagai penyeleksi mikroba; pengaruhnya bisa meningkatkan perkembangan mikroba tertentu dan menghambat perkembangan mikroba lain (Grayston et al., 1998). Semakin banyak eksudasi akar, akan semakin besar jumlah dan keragaman mikroba. Kondisi ini akan meningkatkan persaingan dalam proses kolonisasi rizosfir. Bakteri rizosfir merupakan mikroba kompetitor yang paling efisien yang mampu menggeser kedudukan mikroba pribumi (native) di lingkungan rizosfir sampai pada masa pertengahan umur tanaman (Kloepper \& Schroth, 1981). Peningkatan pertumbuhan tanaman yang diinokulasi dengan Azotobacter dan Azospirillum tidak hanya dari oleh sumbangan nitrogen hasil penambatan N2, namun faktor lain yang berperan dalam peningkatan pertumbuhan tanaman, yakni hormon AIA (asam indol asetat) yang dihasilkan bakteri tersebut (Kennedy, 1998). Hasil yang sama dikemukakan oleh De Freitas et al. (1997) bahwa peningkatan pertumbuhan tanaman kanola (Brassica napus L.) yang diinokulasi dengan rizobakteri pelarut $\mathrm{P}$. Bacillus $\mathrm{sp}$. juga terkait dengan kemampuan bakteri ini menghasilkan hormon pertumbuhan AIA.

AIA yang dihasilkan PGPR seperti Azospirillum brasilense dan Azotobacter paspali meningkatkan jumlah bulu akar dan akar lateral sehingga meningkatkan penyerapan air dan unsur hara dari tanah. Azospirillum brasilense yang menghasilkan beberapa fitohormon juga mampu meningkatkan produktivitas tanaman pearl millet baik secara hormonal maupun dengan penyediaan hara nitrogen. Namun peningkatan pertumbuhan tanaman ini terjadi pada pemberian AIA dengan konsentrasi sangat rendah $(0,01 \mu \mathrm{g}$ $\mathrm{ml}-1$ ), sedangkan pada konsentrasi lebih tinggi cenderung menurunkan pertumbuhan.

Sintesis AIA di dalam tanah dipacu oleh ketersediaan prekursor spesifik (bahan dasar) triptopan (L-tryptophan). Triptopan (salah satu sumber $\mathrm{N}$ bagi mikroba) yang terdapat dalam eksudat akar dan bahan organik dapat diubah oleh mikroba tanah menjadi AIA (Arshad \& Frankenberger, 1993). Sintesis AIA dari triptopan oleh Azospirillum brasilense merupakan cara PGPR mengurangi tingkat konsentrasi triptopan yang bersifat toksik bagi perkembangannya. Diketahui bahwa AIA mempunyai peran fisologis bagi Azospirillum brasilense dan bukan hanya sebagai produk dari hasil proses detoksifikasi (Dosselaere et al., 1997).

Enzim aminocyclopropane carboxylic acid (ACC) deaminase berperan mengurangi pembentukan ACC yang merupakan bahan dasar pembentukan hormon etilen.Hormon etilen selain berfungsi sebagai pemacu tumbuh (mempercepat perkecambahan, perkembangan akar, pembungaan, pematangan buah, dan lain-lain) juga berperan sebagai antagonis atau modulator bagi berbagai fitohormon untuk mencegah pertumbuhan tanaman yang berlebihan (gigantisme). Pembentukan (sintesis) ACC dipacu oleh hormon AIA, dan ACC yang terbentuk akan diubah menjadi hormon etilen yang dalam jumlah besar menghambat pemanjangan (perkembangan) akar baru. Selain memacu perkembangan sel dan akar baru, hormon AIA di dalam jaringan akar juga merangsang pembentukan enzim ACC sintase yang berperan dalam sintesis ACC. Dalam proses kesetimbangan, sejumlah ACC yang terbentuk akan keluar dari akar yang selanjutnya dirombak oleh PGPR penghasil enzim ACC deaminase di lingkungan rizosfir menjadi amonia dan $\alpha$-ketobutirat. Hidrolisis ACC (salah satu sumber $N$ bagi PGPR) secara terus-menerus akan mengurangi jumlah ACC 
dan etilen di dalam akar, sehingga mengurangi pengaruh negatif etilen bagi perkembangan / pemanjangan akar tanaman.

Inokulasi tanaman oleh PGPR ACC deaminase seperti Pseudomonas fluorescens dan Enterobacter cloacae mampu meningkatkan pertumbuhan tanaman.Selain dapat mengurangi pengaruh negatif hormon etilen yang berlebihan, PGPR ini mampu menekan penyakit layu rebah (damping-off) pada bibit mentimum dan penyakit busuk akar pada tomat dan kentang.PGPR penghasil enzim ACC deaminase mampu mengurangi pengaruh negatif etilen bagi pertumbuhan tanaman, juga memiliki kemampuan melindungi tanaman dari berbagai cekaman lingkungan (genangan) dan memfasilitasi produksi senyawa organik volatil untuk fitoremediasi tanah-tanah tercemar logam berat (Glick, 2006; Wang et al., 2006).

Siderophore merupakan senyawa pengompleks $\mathrm{Fe} 3+$ atau pengkhelat besi spesifik yang dihasilkan mikroba untuk menyembunyikan unsur mikro besi di lingkungan rizosfir, sehingga unsur ini tidak tersedia bagi perkembangan mikroba patogen. Beberapa strain PGPR seperti Pseudomonas fluorescens B10 mampu menghasilkan yellowgreen florescent siderophores (disebut pseudobactin) yang dapat menghambat perkembangan jamur patogen Erwinia caratovora penyebab busuk pada kentang (Subba-Rao, 1999). Persaingan antara PGPR dan mikroba patogen dalam mendapatkan unsur besi berimplikasi pada pengendalian penyakit tular tanah (soilborne diseases) seperti penyakit layu rebah yang disebabkan oleh jamur Pythium ultimum (Kloepper, 1993). Produksi siderophore oleh PGPR umumnya terjadi pada tanah - tanah bereaksi netral sampai basa dimana kelarutan $\mathrm{Fe} 3+$ rendah sehingga terjadi kondisi kekurangan unsur besi bagi tanaman dan mikroba.Namun dalam beberapa kasus, pengkhelatan $\mathrm{Fe} 3+$ dari mineral Fe-P dapat pula terjadi sehingga dapat meningkatkan ketersediaan $P$ bagi tanaman (Mullen, 1998).Peran ganda PGPR penghasil siderophore ini dilaporkan oleh Reid et al. (1985) bahwa hydroxamate siderophore yang terdapat di rizosfir secara efektif dapat meningkatkan ketersediaan unsur Fe dan juga
$\mathrm{P}$ pada tanah - tanah masam.Kemampuan pengkhelatan $\mathrm{Fe}$ pada tanah-tanah dengan kandungan Fe-fosfat yang tinggi berimplikasi pada penyediaan hara $P$ bagi tanaman yang sekaligus dapat meningkatkan ketahanan tanaman terhadap patogen. Pengamatan bibit kakao disesuaikan dengan kriteria bibit kakao siap tanam, sehingga waktu pengamatan pada masing-masing parameter berbeda. Kriteria tinggi bibit kakao siap tanam yaitu $45 \mathrm{~cm}$, diameter batang $0,6 \mathrm{~cm}$, jumlah daun minimal 12 helai.

\section{METODOLOGI PENELITIAN}

Penelitian di laksanakan pada bulan Juni Desember 2021, bertempat di lahan pembibitan Politeknik Negeri Jember dengan ketinggian tempat $89 \mathrm{~m}$ dpl. Penelitian ini mengenai respon pertumbuhan bibit kakao (Theobroma cacao L.) dengan pemberiann PGPR(Plant Growth Promoting Rhizobacteria) akar kakao. Alat yang digunakan yaitu : tong plastik, sabit, parang, cangkul, gergaji, palu, roll meter, bambu, belabat, jerigen, kompor gas, panci, pengaduk kayu, oven, bak persemaian, gembor, gelas plastik, gelas ukur, jangka sorong, penggaris, timbangan, ayakan, waring, alat tulis, camera. Bahan yang digunakan yaitu : biji kakao Varietas ICCRI 06, PGPR akar kakao, top soil, pasir, pupuk kandang, polibag, fungisida, bakterisida, paku, kawat.

Penelitian menggunakan RAK non faktorial, yaitu : PO = Konsentrasi PGPR $0 \mathrm{ml} /$ liter $/ 5$ polibag; P1 = Konsentrasi PGPR $50 \mathrm{ml} /$ liter $/$ 5 polibag; $\mathrm{P} 2=$ Konsentrasi $\mathrm{PGPR} 100 \mathrm{ml} /$ liter / 5 polibag; P3 = Konsentrasi PGPR 150 $\mathrm{ml} /$ liter / 5 polibag dan 6 ulangan.

\section{HASIL DAN PEMBAHASAN}

\subsection{Tinggi Bibit Kakao}

Tinggi bibit tanaman dihitung dari permukaan tanah sampai titik tumbuh tanaman kakao. Uji kontras polinomial pengaruh konsentrasi PGPR (Plant Growth Promoting Rhizobakteri) akar kakao terhadap pertumbuhan tinggi bibit kakao 6 MST, 8 MST, 16 MST, nampak pada gambar dibawah ini : 




Gambar1.Grafik Polinomial Tinggi Bibit Kakao Pada Umur 6 MST

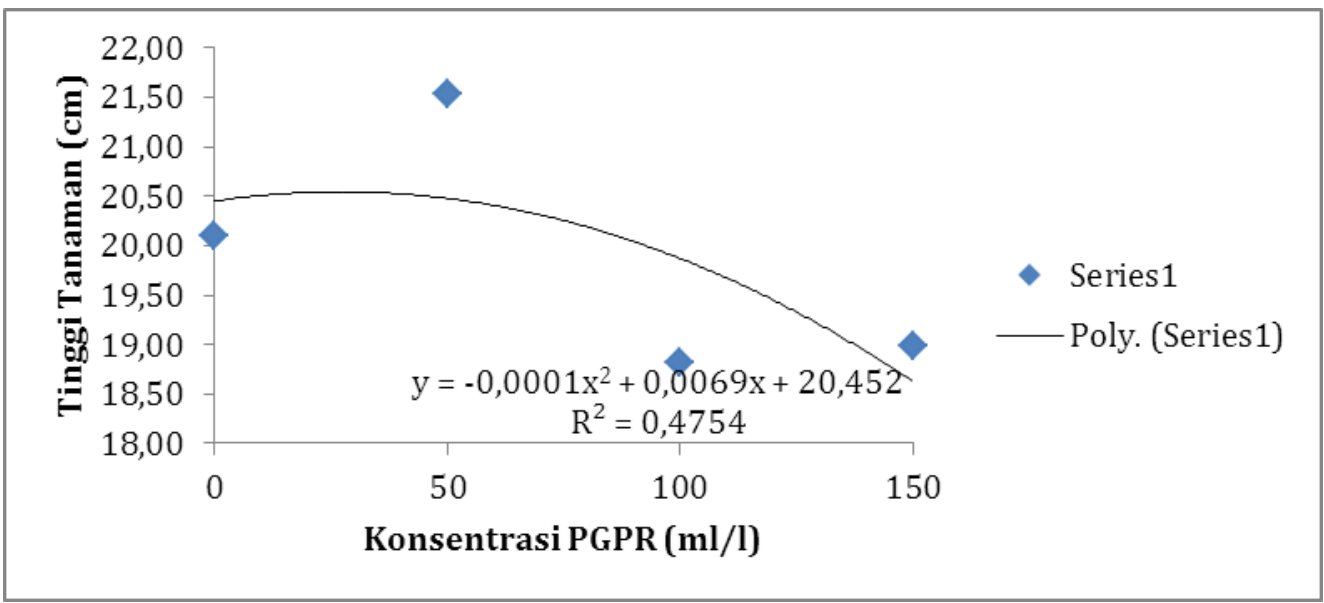

Gambar2.Grafik Polinomial Tinggi Bibit Kakao Pada Umur 8 MST

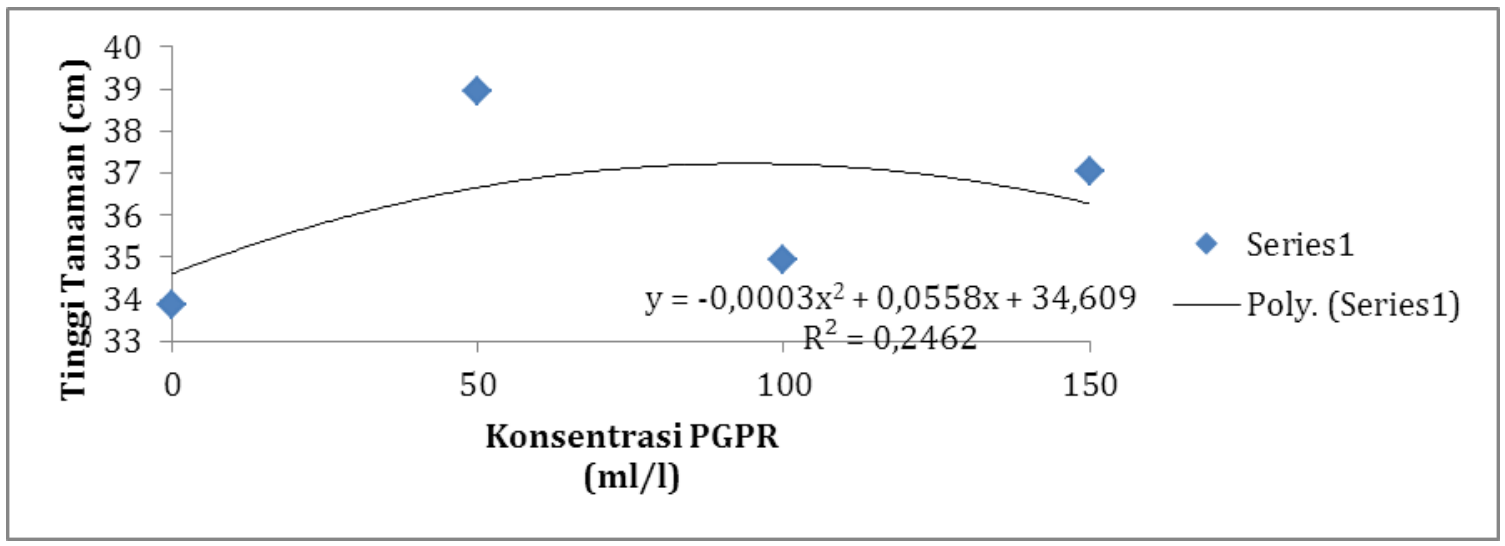

Gambar 3.Grafik Polinomial Tinggi Bibit Kakao Pada Umur 16 MST 
Tinggi tanaman merupakan vase vegetatif pada pembibitan tanaman sehingga dijadikan parameter untuk mengetahui hal perbandingan tiap perlakuan yang di uji.Berdasarkan uji lanjut kontras polinomial diketahui bahwa pengaplikasian konsentrasi PGPR pada umur 6 MST sudah berpengaruh nyata secara perlakuan pada taraf $5 \%$.Pada umur $8 \mathrm{MST}$ berpengaruh nyata secara kubik pada taraf $5 \%$ terhadap tinggi bibit kakao. Pada umur 16 MST berpengaruh nyata secara kubik pada taraf $5 \%$ terhadap tinggi bibit kakao. Grafik polinomial pada tinggi bibit kakao umur 6 MST dan 8 MST masih belum bisa menduga dosis optimum dalam menentukan konsentrasi terbaik pada tinggi tanaman bibit tanaman kakao dikarenakan pada $R^{2}$ koefisien determinasi masih dibawah 0,8 dan masih belum adanya hubungan. Tinggi bibit kakao umur 16 MST mencapai $39 \mathrm{~cm}$ mendekati kriteria bibit kakao siap tanam yaitu $45 \mathrm{~cm}$.

Pemberian konsentrasi PGPR dapat meningkatkan proses metabolisme dalam pertumbuhan tanaman kakao sehingga memacu pertumbuhan vegetatif tinggi tanaman. Dalam pemberian konsentrasi PGPR mampu memberikan unsur hara nitrogen yang dapat mensuplai senyawa organik penting yang dibutuhkan oleh tanaman untuk menunjang pertumbuhan tanaman yang kemudian dibantu oleh unsur hara pospor dalam mentransfer di dalam tanaman.Unsur hara nitrogen terdapat pada Azotobacter atau Rizobakteria yang diketahui sebagai agen biologis dalam menfiksasi nitrogen, yang mampu mengubah nitrogen menjadi amonium melalui reduksi elektron dan protonasi gas nitrogen. Jumlah Azotobacter berbanding lurus dengan total $\mathrm{N}_{2}$ yang dapat di ubah oleh sel Azotobacter.

\subsection{Jumlah Daun Bibit Kakao}

Parameter jumlah daun pada tanaman kakao, dengan mengamati jumlah daun dan menghitung daun yang normal berwarna hijau, daun sudah mekar sempurna dan tidak terserang hama dan penyakit. Pengamatan jumlah daun bibit kakao dilakukan pada umur 2 MST, 6 MST, 10 MST, dan 14 MST karena kriteria jumlah daun bibit kakao siap tanam harus memiliki 20 helai daun. Uji kontras polinomial konsentrasi PGPR akar kakao terhadap pertumbuhan jumlah daun bibit kakao pada umur $2 \mathrm{MST}, 6 \mathrm{MST}, 10 \mathrm{MST}$, dan 14 MST, nampak pada gambar dibawah ini :

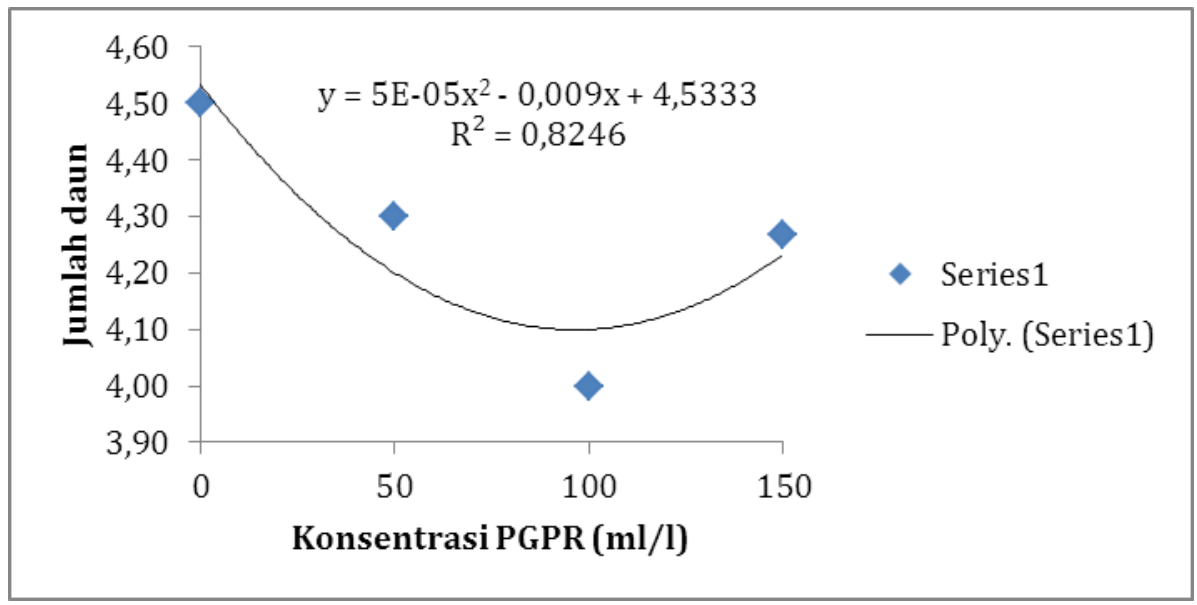

Gambar4. Grafik Polinomial Jumlah Daun Bibit Kakao Pada Umur 2 MST 




Gambar 5. Grafik Polinomial Jumlah Daun Bibit Kakao Pada Umur 6 MST

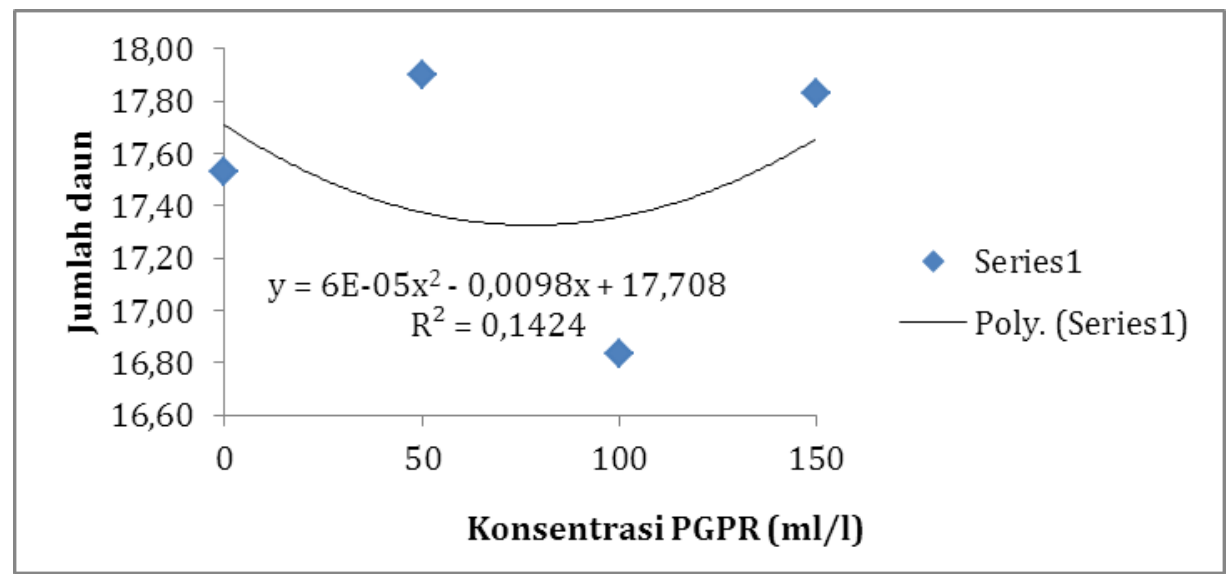

Gambar 6. Grafik Polinomial Jumlah Daun Bibit Kakao Pada Umur 10 MST

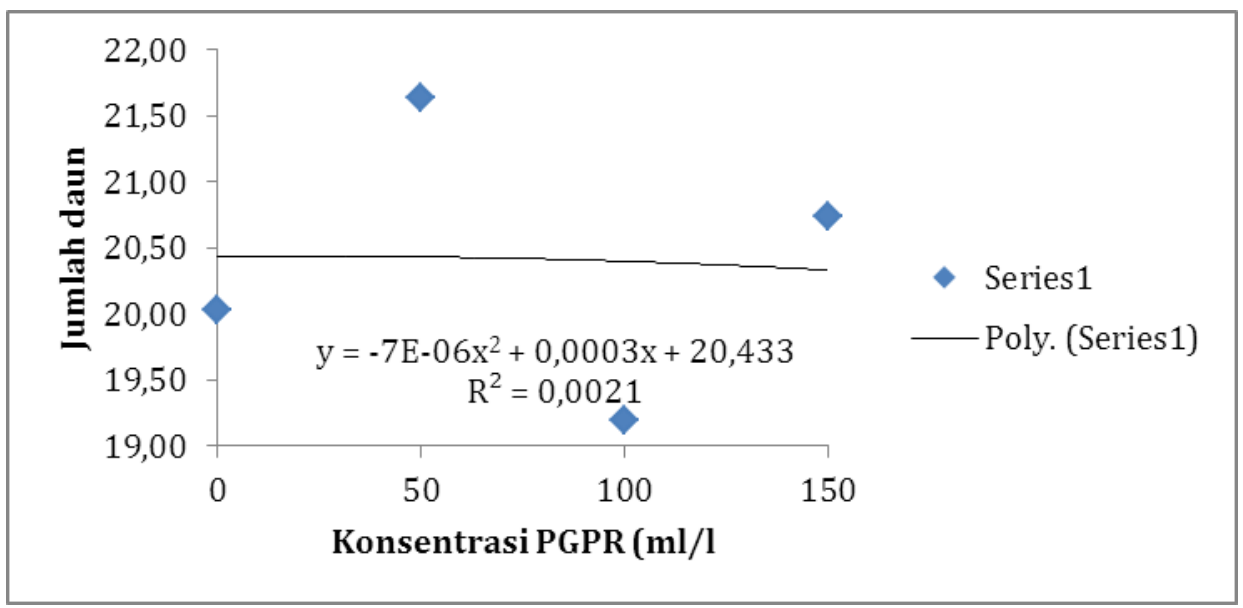

Gambar 7. Grafik Polinomial Jumlah Daun Bibit Kakao Pada Umur 14 MST 
Berdasarkan uji lanjut kontras polinomial dapat diketahui jumlah daun pada umur 2 MST sudah berpengaruh nyata secara kuadratik pada taraf $5 \%$. Pada umur 6 MST berpengaruh nyata secara kubik pada taraf $5 \%$. Pada umur 10 MST berpengaruh nyata secara kubik pada taraf 5\%. Pada bibit kakao umur 10 dan 14 MST jumlah daun sudah mencapai lebih dari 12 helai daun sesuai dengan kriteria bibit kakao siap tanam. Pemberian PGPR dapat meningkatkan bahan organik dalam tanah dan dapat membantu aktifitas mikroorganisme di dalam tanah. Hal ini dikarenakan bakteri pada perakaran dalam tanah merupakan sumber makanan, energi dan karbon bagi mikroorganisme.

Mikroorganisme berperan dalam vase vegetatif atau pun generatif pada tanaman. Unsur hara $\mathrm{N}$ merupakan unsur yang berperan terhadap pertumbuhan dan perkembangan daun. Unsur hara yang sangat berpengaruh terhadap pertumbuhan tanaman dan perkembangan daun adalah unsur hara $\mathrm{N}$ yang juga berperan dalam sintesis klorofil, asam amino dan protein sehingga mampu membentuk organ-organ pertumbuhan diantaranya pembentukan daun.

3.3 Diameter Batang Bibit Kakao

Diameter batang bibit tanaman dilakukan dengan mengukur $1 \mathrm{~cm}$ dari permukaan tanah yang telah diberi tanda dengan bambu yang tertanam dipermukaan tanah sedalam $1 \mathrm{~cm}$. Uji kontras polinomial konsentrasi PGPR asal akarkakao terhadap pertumbuhan diameter batang bibit tanaman kakaopada beberapa konsentrasi PGPR asal akar kakao, nampak pada gambar dibawah :

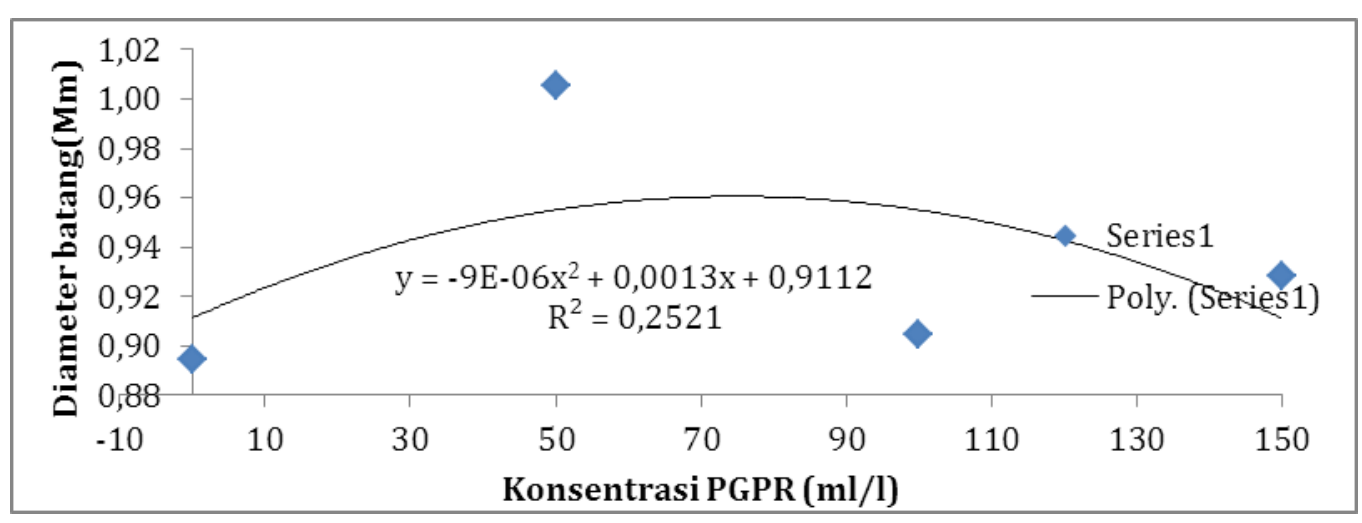

Gambar 8. Grafik Polinomial Diameter Batang Bibit Kakao Pada Umur 16 MST

Berdasarkan uji lanjut kontras polinomial dapat diketahui bahwa pada umur 16 MST diameter batang sudah berpengaruh nyata secara kubik pada taraf $1 \%$ terhadap diameter batang bibit tanaman kakao. Grafik polinomial pada diameter batang bibit tanaman kakao umur 16 MST masih belum bisa menduga dosis optimum dalam menentukan konsentrasi terbaik pada diameter batang bibit tanaman kakao dikarenakan pada $\mathrm{R}^{2}$ koefisien determinasi masih dibawah 0,8 dan masih belum adanya hubungan.

\subsection{Berat Basah dan Berat Kering Akar Bibit Kakao}

Berat basah bibit tanaman kakao dilakukan dengan mengambil 2 sampel tanaman acak 2 tanaman dari setiap plot. Setelah itu tanaman dicabut dan dibersihkan dari tanah. Uji kontras polinomial konsentrasi PGPR terhadap pertumbuhan berat basah akar bibit kakao, nampak pada gambar dibawah ini: 


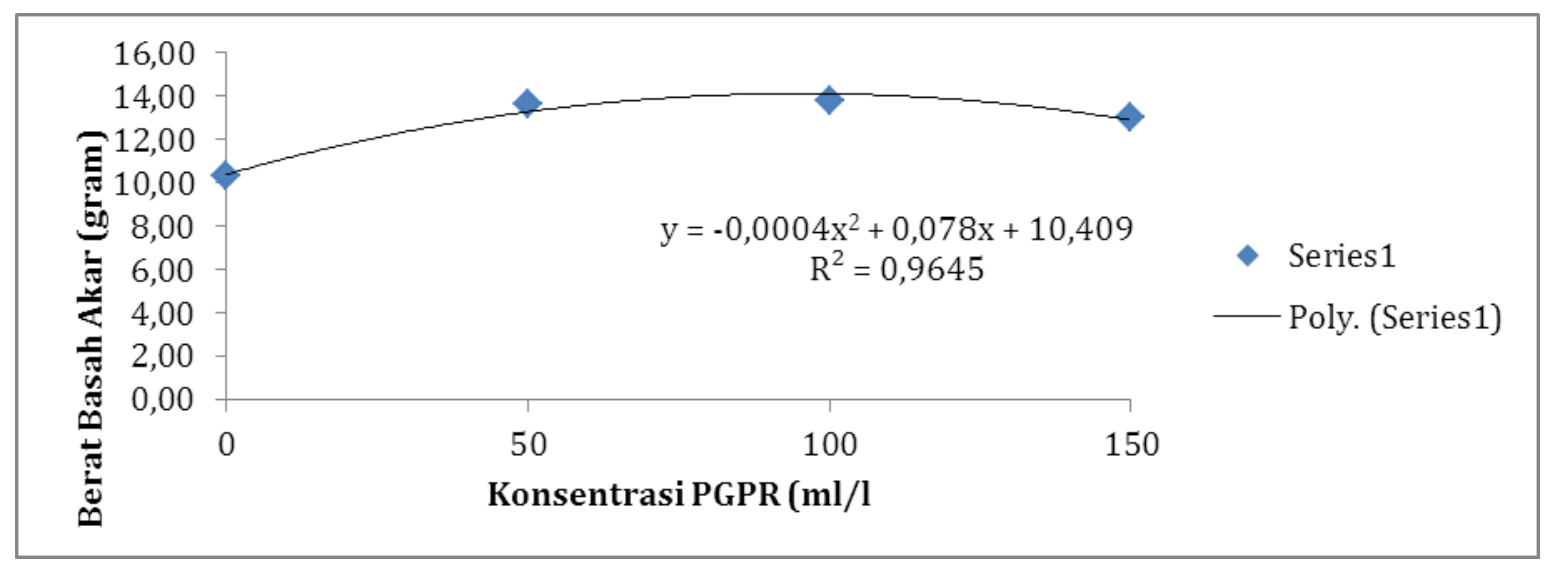

Gambar 9. Grafik Polinomial Berat Basah Akar Bibit Kakao Pada Umur 16 MST

Berat basah akar merupakan vase vegetatif pada pembibitan tanaman sehingga dijadikan parameter untuk mengetahui hal perbandingan tiap perlakuan yang di uji. Berdasarkan uji lanjut kontras polinomial dapat diketahui bahwa dalam pengaplikasian konsentrasi PGPR berpengaruh nyata secara kuadratik pada taraf $1 \%$ pada berat basah akar. Dosis yang optimum untuk berat basah akarbibit tanaman kakao adalah $99 \mathrm{ml} / \mathrm{l}$.
Konsentrasi PGPR akar kakao berpengaruh nyata pada berat basah akar bibit tanaman kakao. PGPR terdapat bakteri Bacillussp yang mampu memproduksi IAA (Indol Asam Asetat) sehingga meningkatkan berat basah akar, melarutkan fosfat dan agen biokontrol dengan menginduksi sistem kekebalan pada tanaman. Uji kontras polinomial konsentrasi PGPR asal akar kakao terhadap pertumbuhan berat kering bibit kakao, nampak pada gambar berikut :

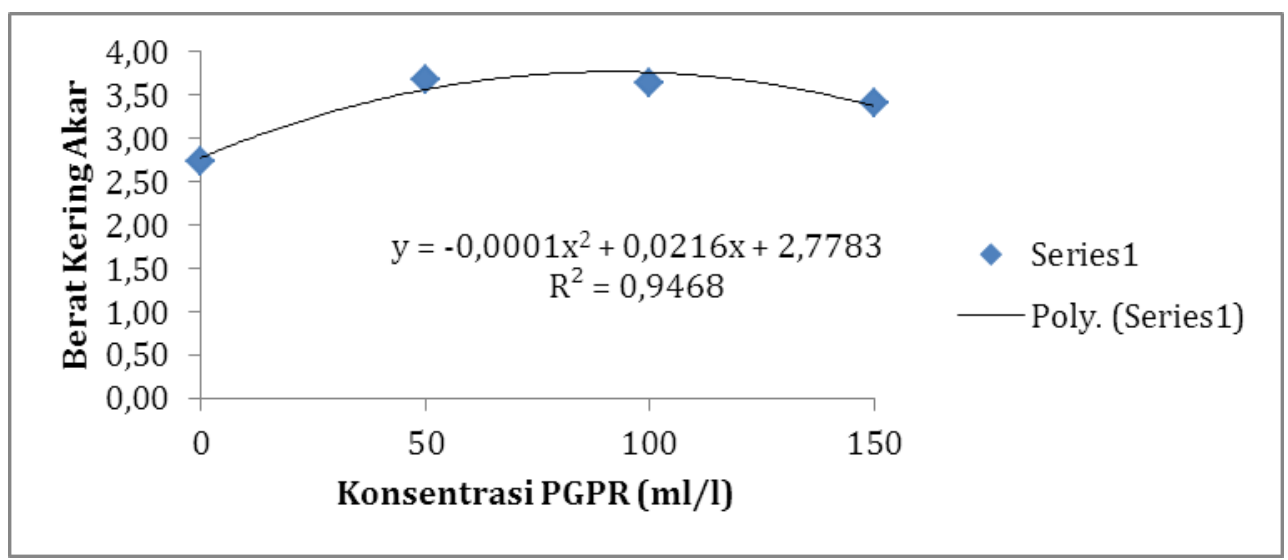

Gambar 10. Grafik Polinomial Diameter Berat Kering Akar Bibit Kakao Pada Umur 16 MST

Berdasarkan uji lanjut kontras polinomial dapat diketahui bahwa dalam pengaplikasian konsentrasi PGPR berpengaruh nyata secara kuadratik pada taraf $1 \%$ pada berat kering akar. Dosis yang optimum untuk berat kering akar bibit tanaman kakao adalah $109 \mathrm{ml} / \mathrm{l}$. Bakteri PGPR memiliki kemampuan sebagai penyedia unsur hara pada tanaman yang disebabkan oleh kemampuannya melarutkan mineral-mineral dalam bentuk senyawa kompleks menjadi bentuk ion sehingga dapat diserap oleh akar tanaman, Menurut penelitian
(Jumin, 2002) bahwa ketersediaan unsur hara sangat menentukan produksi berat kering tanaman yang merupakan hasil dari tiga proses yaitu proses penumpukan asimilat yang melalui proses fotosintesis, respirasi dan akumulasi senyawa organik.

\subsection{Jumlah Akar Bibit Kakao}

Uji kontras polinomial konsentrasi PGPR akarkakao terhadap pertumbuhan jumlah akar bibit, nampak pada gambar dibawah ini : 


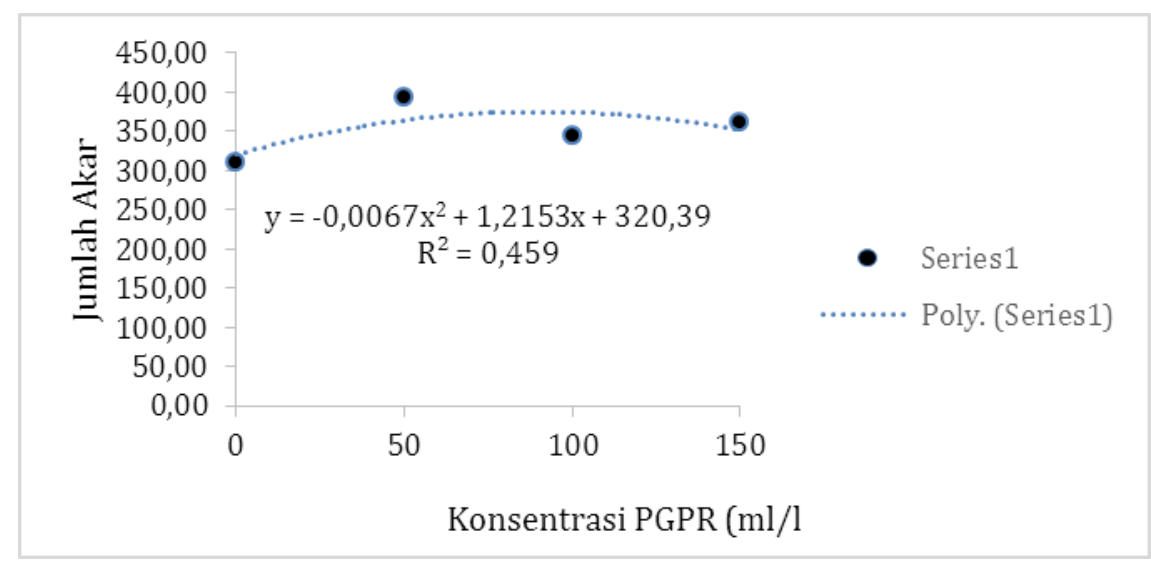

Gambar 11.Grafik Polinomial Jumlah Akar Bibit Kakao Pada Umur16 MST.

Berdasarkan uji lanjut kontras polinomial dapat diketahui bahwa dalam pengaplikasian konsentrasi PGPR berpengaruh nyata secara kubik pada taraf $5 \%$ pada jumlah akar. Grafik polinomial pada jumlah akar bibit tanaman kakao umur 16 MST masih belum bisa menduga dosis optimum dalam menentukan konsentrasi terbaik pada jumlah akar bibit tanaman kakao dikarenakan pada $\mathrm{R}^{2}$ koefisien determinasi masih dibawah 0,8 dan masih belum adanya hubungan.

Mekanisme PGPR dalam meningkatkan pertumbuhan tanaman terkait dengan kompleksitas peran PGPR bagi pertumbuhan tanaman dan beragamnya kondisi fisik, kimia, dan biologi di lingkungan rizosfir. Diyakini bahwa proses pemacuan tumbuh tanaman dimulai dari keberhasilan PGPR dalam pengkolonisasi rizosfir. PGPR akar kakao mampu meningkatkan mikroorganisme didalam tanah, sehingga mikroorganisme mampu menyuplai unsur hara tanamann untuk mendukung perkembangan akar serta memperluas jangkauan akar dalam penyerapan air dan unsur hara.

\subsection{Volume Akar Bibit Kakao}

Uji kontras polinomial konsentrasi PGPR asal akar kakao terhadap pertumbuhan berat basah bibit tanaman kakaopada beberapa konsentrasi PGPR asal akar kakao ditunjukkan pada gambarberikut :

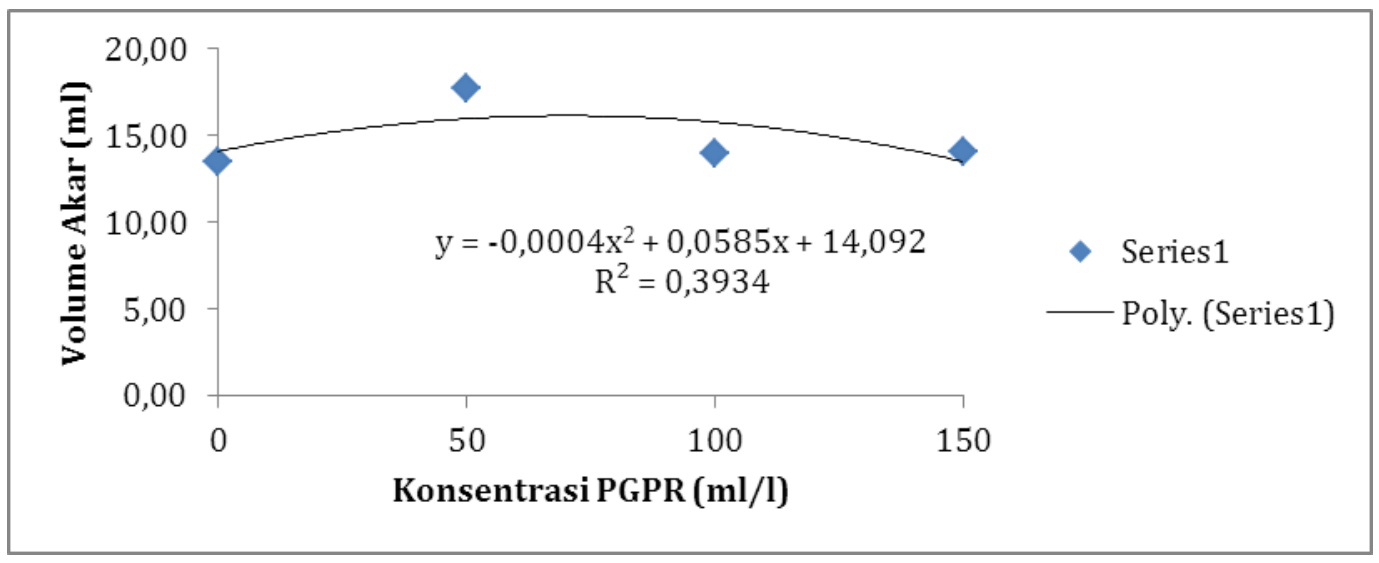

Gambar 11. Grafik Polinomial Volume Akar Bibit Kakao Pada Umur 16 MST

Volume akar merupakan vase vegetatif pada pembibitan tanaman sehingga dijadikan parameter untuk mengetahui hal perbandingan tiap perlakuan yang di uji.Berdasarkan uji lanjut kontras polinomial dapat diketahui bahwa dalam pengaplikasian konsentrasi PGPR berpengaruh nyata secara kubik pada taraf $1 \%$ pada volume akar.

\section{KESIMPULAN \\ Kesimpulan}

1. Respon Pertumbuhan Bibit Kakao (Theobroma cacao L.) Dengan Pemberian PGPR (Plant Growth Promoting Rhizobacteria) Akar Kakao berpengaruh nyata terhadap tinggi tanaman, jumlah daun, diameter batang, berat basah dan 
berat kering akar, jumlah akar dan volume akar.

2. Pemberian konsentrasi PGPR akar kakao yang optimal terhadap berat kering akar : $109 \mathrm{ml} /$ / dan berat basah akar : $99 \mathrm{ml} /$ /

\section{DAFTAR PUSTAKA}

Arshad, M. and W.T. Frankenberger, Jr. 1993.Microbial production of plant growth regulators. p. 307-347. In F.B. Meeting, Jr. (Ed.). Soil Microbial Ecology. Applications in Agricultural and Environmental Management. Marcel Dekker, Inc. New York.

Cattelan, A.J., P.G. Hartel, and J.J. Fuhrmann. 1999. Screening for plant Growth promoting rhizobacteria to promote early soybean growth. Soil Sci. Soc. Am. J. 63: 1.670-1.680.

De Freitas, J.R., M.R. Banerjee, and J.J. Germida. 1997. Phosphate-solubilizing rhizobacteria enhance the growth and yield but not phosphorus uptake of canola (Brassica napus L.). Biol. Fertil. Soils 24: 358-364.

Dosselaere, E., A.V. Broek, M. Lambrecht, P. De Troch, E. Prinsen, Y. Okon, V. Keijers, and J. Vanderleyden. 1997. Indole-3-acetic bisynthesis in Azospirillum brasilense. p. 306-309. In A. Ogoshi et al. (Eds.).Plant GrowthPromoting Rhizobacteria, Present status and Future Prospects.Proceedings of the Fourth International Workshop on PGPR.Japan-OECD Joint Workshop. Sapporo, Japan. October 5-10, 1997.

Grayston, S.J., S. Wang, C.D. Campbell, and A.C. Edwards. 1998. Selective influence of plant species on microbial diversity in the rhizosphere. Soil Biol. Biochem. 30: 369-378.

Glick, B.R. 1995. The enhancement of plant growth by free-living bacteria. Can. J. Microbiol. 4: 109-117.

Kennedy, A.C. 1998. The rhizosphere and spermosphere. p. 389-407. In Silvia et al. (Eds.).Principles and Application of Soil Microbiology. Prentice Hall. New Jersey.
Kloepper, J.W. and M.N. Schroth. 1981. Relationship in vitro antibiosis of plant growth promoting rhizobacteria on potato plant development and yield. Phytopathology 70: 1.078-1.082.

Kloepper, J.W., W. Mahaffee, J.A. Mcinroy, and P.A. Backman. 1991. Comparative analysis of isolation methods for recovering root-colonizing bacteria from roots. p. 252-255. In C. Keel, B. Koller, and G. Defago (Eds.).Plant Growth Promoting Rhizobacteria - Progress and Prospects. The Second International Workshop on PGPR. Interlaken, Switzerland, October 14-19, 1990.

Kloepper, J.W. 1993. Plant growth promoting rhizobacteria as biological control agents. p. 255-274. In F.B. Meeting, Jr. (Ed.). Soil Microbial Ecology, Applications in Agricultural and Environmental Management. Marcel Dekker, Inc. New York.

Mullen, M.D. 1998.Transformation of other elements. p. 369-386. In Silvia et al. (Eds.).Principles and Application of Soil Microbiology.Prentice Hall. New Jersey.

Reid, R. K., C.P.P. Reid, and P.J. Szaniszlo. 1985. Effect of synthetic and microbially produced chelates on the diffusion of iron and phosphorus to a simulated root in soil. Biol. Fertil. Soils 1: 45-52.

Sorensen, J. 1997. The rhizosphere as a habitat for soil microorganisms. p. 2145. In J.E. Van Elsas, J.T Trevors, and E.M.H. Wellington (Eds.).Modern Soil Microbiology. Marcel Dekker, Inc. New York.

Subba-Rao, N.S. 1999. Soil Microbiology (Fourth Edition of Soil Microorganisms and Plant Growth). Science Publishers, Inc. USA.

Tenuta, M. 2006. Plant Growth Promoting Rhizobacteria: Prospect for increasing nutrient acquisition and disease control. Available:

http://www.umanitoba.ca/afs/agronomis ts conf/2003/pdf/tenuta rhizbacteria.pd $f$. [Accessed 22 July 2006]. 
Wang, C., E. Knill, B.R. Glick, and G. Défago. 2006. An ACC deaminase gene improves the growth-promoting and disease-suppressive capacities of Pseudomonas fluorescens Strain
CHA0. Auburn University Web Site, Available: http:// www.ag.auburn.edu / argentina / pdfmanuscripts kloepper.pdf. [Accessed 30 June 2006]. 